Keywords

protein array; post-translation; phosphorylation; kinase

\title{
INTRODUCTION
}

Protein microarrays allow unique approaches for interrogating global protein interaction networks. Protein arrays can be divided into two categories: antibody array and functional

\footnotetext{
(c) 2013 by John Wiley \& Sons, Inc.

Internet Resources

http://www.invitrogen.com/site/us/en/home/LINNEA-Online-Guides/LINNEA-Guide-to-Clones/Ultimate-ORF-Clones.html Invitrogen's Ultimate ORF clone information Web site has more details on available cDNA collections and expression strategy using GATEWAY technology

http://www.invitrogen.com/site/us/en/home/Products-and-Services/Applications/Protein-Expression-and-Analysis/BiomarkerDiscovery/ProtoArray/Resources/Data-Analysis.html

Information about Invitrogen's Prospector software to analyze protein array data.

http://www.openbiosystems.com

Web site for OpenBiosystems, a distributor of many of cDNA collection now owned by Thermo.

http://www.origene.com

Web site for Origene. It houses expression validated cDNA clones.

http://dnasu.asu.edu/DNASU

Web site for the ASU biodesign institute. An academic resource for obtaining various mammalian cDNA collections and expression vector plasmid for nominal fee.

http://ymd.med.yale.edu/kei-cgi/kc_mac_dev8.pl

MicroArray Convolutor. Web tool for generating gal file for microarray analysis.
} 
protein array. Antibody arrays consist of various immobilized antibodies and are best used for profiling protein abundance and modifications (Schweitzer and Kingsmore, 2002). Functional full-length protein arrays have full-length proteins with various post-translational modifications. A key advantage of the latter is rapid parallel processing of large numbers of proteins for the study of highly controlled biochemical activity, protein-protein interactions, protein-nucleic acid interactions, and protein-small molecule interactions.

Despite these advantages, high costs, the length of time required for preparations, and numerous technical difficulties in producing proteins for the arrays have been noted as downsides of this technology. However, the technology has successfully been used to screen for protein-protein, protein-nucleic acid, and protein-small molecule interactions (MacBeath and Schreiber, 2000; Zhu et al., 2001; Hu et al., 2009; Tsvetanova et al., 2010; Fasolo et al., 2011).

This unit presents a protocol for constructing functional yeast protein microarrays for global kinase substrate identification (Fig. 27.4.1). More than 5500 fusion proteins TAP-tagged at their carboxy-termini are purified in 96-well format (Basic Protocol 1) and spotted onto nitrocellulose-coated slides in a spatially addressable manner (Basic Protocol 2 and Gelperin et al., 2005). Purified kinase of interest and radiolabeled ATP is incubated on a protein microarray, which is then washed, dried, and analyzed by autoradiography (Basic Protocol 3). The phosphorylated spots are quantified and normalized, and proteins that are reproducibly phosphorylated in the presence of active kinase relative to the control slides are scored as positive substrates. This approach enables the rapid determination of protein interaction networks in yeast on a proteome-wide level and can be readily adapted to higher eukaryotic systems.

\section{STRATEGIC PLANNING}

Protein microarrays allow the investigator to ask whole-organism level questions and gain a perspective on the biology of proteins. However, constructing a proteome microarray is not a simple task. The need for preparation of a collection of highly validated cDNA, as well as expression and purification of proteins in large numbers, require careful planning and optimization. In addition, certain aspects of this protocol require cross-disciplinary expertise such as array design, data acquisition, and the analysis of large amounts of data.

\section{Building Expression Collections}

One of the most critical but time consuming steps in constructing protein microarrays is building a fully sequenced, high-quality cDNA collection. It is very important to use a highquality cDNA collection to eliminate downstream ambiguity. Currently, both commercial and institutional sources exist that provide numerous collections from various species. These include Open Biosystems (http://www.openbiosystems.com), Origene (http:// www.origene.com), ASU biodesign institute (http://dnasu.asu.edu/DNASU), Invitrogen, Caenorhabditis elegans ORFeome project (Hudson et al., 1997), human fetal brain Unigeneset (Reboul et al., 2003), FLEX gene repository at Harvard Institute of Proteome (Bussow et al., 2000; Brizuela et al., 2001), I.M.A.G.E. cDNA collection (Lennon et al., 1996), and MGC collection (Strausberg et al., 1999, 2002). The choice of overexpression 
system, promoter, and fusion tags also affect the yield of protein production (Graslund et al., 2008); however, such topics are beyond the scope of the current unit. Several highthroughput cloning methods are available for rapid transfer of cDNA from a donor collection (source) to expression vectors (destination). Gateway (Invitrogen) and Flexi Vector (Promega) systems provide the most variety and high efficiency in cloning, although the cost of reagents can be prohibitive for small laboratories. Other products like Creator or InFusion (Clontech) systems are also available. Although it lacks flexibility, a ligationindependent cloning strategy (Popescu et al., 2007) provides the most cost-effective approach for high-throughput cloning with high efficiency. It is recommended to test several vectors initially to identify potential pitfalls or problems before committing to one expression vector.

\section{Preparing Controls}

Inclusion of thoughtful controls is key in setting up protein microarray experiments. Controls are necessary to interpret and troubleshoot the results and assist the processing of downstream data analysis steps. In particular, the corner positions of all blocks are reserved for landmark controls to help locate the protein spots. For example, in the case of a kinase assay, autophosphorylating kinase is positioned at two corners of each block. In addition to the landmark proteins commonly used, histone $\mathrm{H} 1$ is included to monitor the enzyme activity and, if there are other known positive and negative controls, it is advisable to include them, as well.

\section{BASIC PROTOCOL 1: PROTEIN INDUCTION AND PURIFICATION OF PROTEINS FOR PRINTING}

This protocol describes the culture, induction of expression, and purification of proteins for printing. The yeast expression construct used in this procedure is under uracil selection and the gal promoter drives protein expression. Suitable selection and induction reagents should be used according to the expression construct used.

\section{Materials}

TAP-tagged yeast strains (see Strategic Planning)

SC-ura medium, agar plates and liquid (see recipe)

YP $+6 \%$ galactose (see recipe)

Milli-Q water, ice-cold

Lysis buffers 1, 2, and 3 (see recipes)

Elution buffer (see recipe)

IgG Sepharose 6 Fast Flow (GE Healthcare Life Sciences, cat. no. 17-0969-02)

Paint shaker (Harbil 5G-HD) or bead beater (MP bioscience)

GST-3C (prepared in-house) or PreScission 3C protease (GE Healthcare Life Sciences, cat. no. 27-0843-01) 


\section{Histone H1 (Sigma)}

96-pin replicator device (Boekel, cat. no. 140500)

$30^{\circ} \mathrm{C}$ incubator with shakers fitted for $50-\mathrm{ml}$ conical tubes

96-well deep-well round-bottom plate (Nunc)

3.5-mm glass beads, autoclaved (PGC Scientifics, cat. no. 41-5500-06)

Multichannel pipettor: 2- to $20-\mu 1,5-$ to $100-\mu 1$, and 1-ml

\#x02022; Gas-permeable seal (Qiagen, Airpore)

50-ml flip-top conical tubes

8-mm glass beads, autoclaved (PGC Scientifics, cat. no. 41-5500-21)

Tabletop centrifuge with 50-ml conical tube and microplate carriers (Sorvall, cat. no. RTH-250)

Vortex mixer

96-well deep-well plates with fitted silicone mat seals (Dot Scientific, cat. no. R6530)

Paper towels

0.5-mm glass beads (USA Scientific, cat. no. 7400-2405)

Platform rotator

Wide-bore pipet tips, $200 \mu \mathrm{l}$

1.2- $\mu \mathrm{m}$ pore hydrophilic PVDF filter plates (Millipore)

96-well deep-well round-bottom plates with fitted silicone mat seals (Dot Scientific, cat. nos. PC92271-NS9, R618-NS9)

96-well microtiter plates (USA Scientific, cat. nos. 1830-9610)

$0.65-\mu \mathrm{m}$ pore hydrophilic low-protein-binding filter plates (Millipore)

Glutathione Sepharose beads (e.g., Glutathione Sepharose 4B; GE Healthcare Life Sciences, cat. no. 27-4574-01)

384-well flat-bottom polypropylene plates

\section{Grow cells and induce expression of proteins}

All steps must be performed using sterile technique. Starting a seed culture from fresh clones for protein induction gives better yield.

1 Using a 96-pin replicator, pick out TAP-tagged yeast strains onto a SC-ura agar plate and incubate in a $30^{\circ} \mathrm{C}$ incubator.

Yeast colonies should take about 2 days to grow.

It is reasonable to process up to four plates a day. 
2 Prepare $2 \mathrm{ml}$ 96-well round-bottom deep-well culture plate by adding a $3.5-\mathrm{mm}$ glass bead and $800 \mu \mathrm{l}$ SC-ura medium to each well.

Glass beads assist in aeration of the growth medium.

Round-bottom deep-well plates performed best in our hands.

3 Inoculate starter cultures using a multichannel pipettor to add cells row by row. Touch each colony of cells gently and then eject the tips into the wells of the plate and manually swirl each tip in each well and discard the tips. Seal the box with gas-permeable plate seals.

To control for contamination, do not inoculate one or two wells at the corner (these are blanks). If an outgrowth is observed in these wells, it will be necessary to inoculate a new plate from fresh seed culture.

4 Incubate starter cultures overnight in a shaking incubator $(\sim 200 \mathrm{rpm})$ at $30^{\circ} \mathrm{C}$.

Some clones grow more slowly than others due to toxicity of the overexpressed proteins and thus require more growth time. We mark these clones and later assemble additional plates for separate induction.

5 Prepare 50-ml conical tubes for outgrowth culture by adding an 8-mm glass bead and $20 \mathrm{ml} \mathrm{SC}$-ura/raffinose medium to each tube.

The number of tubes required will be determined by how many 50-ml tube racks can fit on a shaking incubator.

Using snap-cap 50-ml tubes, a label printer for labeling tubes and a liquid dispenser will help to reduce processing time significantly.

6 Inoculate outgrowth cultures by adding $400 \mu \mathrm{l}$ of each starter culture to a prepared 50-ml conical tube.

Using a 24-in. $\times 22$-in. platform shaker and a wire rack that holds $48 \times$ 50-ml tubes, four 96-well boxes can be cultured.

7 Incubate outgrowth cultures for $15 \mathrm{hr}$ at $30^{\circ} \mathrm{C}$ to an $\mathrm{OD}_{600}$ of 0.8 .

It has been reported that for some proteins, induction at $\mathrm{OD}_{600}$ of 1 results in higher yields. Longer culture times lead to gas build-up in the tubes and this can cause the snap-cap to pop open with concomitant loss of medium.

8 Induce protein expression by adding $10 \mathrm{ml}$ of $3 \times \mathrm{YP}+6 \%$ galactose (this yields final concentrations of $1 \%$ yeast extract, $2 \%$ peptone, and $2 \%$ galactose) and allow cells to grow another $6 \mathrm{hr}$.

9 Collect the cells by centrifuging cultures for $5 \mathrm{~min}$ at $1000 \times g, 4^{\circ} \mathrm{C}$.

10 Carefully decant the medium, retaining the glass bead in the culture tube.

11 Vortex briefly $(15 \mathrm{sec})$ to resuspend cells in residual medium.

12 Transfer the cells into a new 96-well, deep-well box. 
13 Wash the cells by adding $1 \mathrm{ml}$ ice-cold Milli-Q water to each well and then centrifuging $5 \mathrm{~min}$ at $1000 \times g, 4^{\circ} \mathrm{C}$.

14 Remove water by inverting each plate over a paper towel and tapping gently on the benchtop.

The cell pellets can be stored for up to a month after sealing the 96-well deep-well plate with a fitted polypropylene seal and placing the box at $-80^{\circ} \mathrm{C}$. When ready to proceed to purification, thaw the cell pellets on ice.

\section{Purification of yeast proteome}

We recommend processing a maximum of four 96-well deep-well plates at one time.

15 Prepare fresh lysis and elution buffers and keep chilled. Perform the remaining steps of protein purification at $0^{\circ}$ to $4^{\circ} \mathrm{C}$ (on ice or in the cold room).

16 Equilibrate IgG sepharose beads by washing three times, each time using five volumes of lysis buffer 1 .

A total of $40 \mu \mathrm{l}$ of IgG bead slurry is used for each cell pellet and should be resuspended in the same volume and added to each well of a fresh 96-well round-bottom box.

\section{Prepare crude lysates}

17 Crude lysates are obtained through two rounds of lysis, once using lysis buffer 1 and once using lysis buffer 2. To perform the first round of lysis, add $300 \mu \mathrm{l}$ of 0.5 -mm glass beads and $200 \mu \mathrm{l}$ lysis buffer 1 into each well of the 96-well deepwell plate. Seal the plate with fitted silicone mat. Shake in paint shaker three times for 2 min each time with a 1 min break in between on ice. Pellet the glass beads and cell debris by centrifuging for $5 \mathrm{~min}$ at $1000 \times \mathrm{g}, 4^{\circ} \mathrm{C}$. Use a pipet with wide-bore tips to transfer the supernatant into a $1.2-\mu \mathrm{m}$ pore hydrophilic PVDF filter plate.

18 Filter the resulting supernatant through a 1.2- $\mu \mathrm{m}$ pore hydrophilic PVDF filter plate positioned above a 96-well deep-well round-bottom plate containing the equilibrated $\operatorname{IgG}$ sepharose beads by centrifuging for $5 \mathrm{~min}$ at $250 \times \mathrm{g}, 4^{\circ} \mathrm{C}$.

Alternatively, if using a bead beater (MP Bioscience) for lysis, transfer the pellet into 2-ml screw-cap tubes. Beat the tubes for $30 \mathrm{sec}$ twice with a 1 min break in between at power setting 6 . Centrifuge the tubes at maximum speed for $5 \mathrm{~min}$ at $20,000 \times \mathrm{g}, 4^{\circ} \mathrm{C}$, and transfer the supernatant to the filter plate/collection plate stack as described in step 17.

19 Perform the second round of lysis with new fitted silicone mat in the same manner using $200 \mu \mathrm{l}$ lysis buffer 2 for each well and a fresh filter plate. Combine the lysates from the first and second rounds.

Two-step lysis ensures maximum recovery of proteins. 
20 Add $400 \mu \mathrm{l}$ lysis buffer 3 to the bead and lysate mixtures to adjust the salt concentration to $\sim 150 \mathrm{mM}$.

21 Seal the 96-well round-bottom plate with a fitted silicone mat and agitate for 2 hr to allow the TAP-tagged proteins to bind to the beads. Manually invert the plate two to three times during incubation.

22 Centrifuge the 96-well deep-well plate for 2 min at $250 \times g, 4^{\circ} \mathrm{C}$, and carefully decant the supernatant. Add $800 \mu \mathrm{l}$ lysis buffer 1 into each well to wash the beads.

23 Incubate the beads for 5 min with gentle agitation. Repeat wash four more times.

\section{Elute bound proteins using GST-3C}

Bound fusion proteins can be cleaved from the beads using a site-specific protease. Added protease is cleared by GST bead incubation.

24 Resuspend bound beads using another $600 \mu \mathrm{llysis}$ buffer 1 for each well and using wide-bore tips, transfer them into a $0.65-\mu \mathrm{m}$ pore filter plate affixed onto a microtiter plate. Repeat until all of the beads are transferred.

25 Centrifuge in a tabletop centrifuge for $2 \mathrm{~min}$ at $250 \times \mathrm{g}, 4^{\circ} \mathrm{C}$, to remove buffer. Affix a new microtiter plate under the filter plate.

26 Add $40 \mu \mathrm{l}$ elution buffer and $1 \mu \mathrm{l}$ GST-3C or PreScission 3C protease to each well of the filter plate.

27 Place the microtiter plate with affixed filter plate on a rotating platform shaker and allow the cleavage reaction to proceed overnight in the cold room.

28 Equilibrate glutathione sepharose beads by washing three times using five volumes of elution buffer, and add to cleavage reaction.

Twenty microliters of glutathione bead slurry is used for each well and should be resuspended in minimal volume.

29 Incubate on a platform shaker for one more hour allowing the GST-3C to bind to the glutathione beads. Centrifuge in a tabletop centrifuge for $5 \mathrm{~min}$ at maximum speed, $4^{\circ} \mathrm{C}$. Recover the flow-through, which contains the protein of interest.

Purified proteins can be snap-frozen in an ethanol/dry ice slurry and stored at $-80^{\circ} \mathrm{C}$. Be careful when dipping the plate to make sure ethanol does not get into the wells.

30 Manually rearray four 96-well plates containing purified proteins into a 384-well plate.

This should be done by first thawing the plates on ice and adding control mixtures to the control wells. In addition to buffer-only controls, positive control mixtures for array kinase assays typically include histone $\mathrm{H} 1$ (a generic protein kinase substrate) and PKA (a kinase that readily autophosphorylates), as these mixtures help with 
orienting each block upon autoradiography exposure. One part of the aliquot can be used to perform an immunoblot analysis to check for recovery. Alternatively, rearraying can be done using a liquid handler. Typically, the purified proteins are transferred into multiple plates at 5 to $7 \mu \mathrm{l}$ of purified materials per well to avoid repeated freezing and thawing of protein samples. We typically obtain $\sim 35 \mu \mathrm{l}$ of purified materials and end up making four replicate plates.

\section{BASIC PROTOCOL 2: PRINTING OF PROTEOME MICROARRAYS}

The following describes the procedure to prepare and print microarrays using a contact array printer. Preparation and printing procedures will differ depending on the model of the printer; however, general procedures should be similar. Of note, depending on the surface chemistry of the slides, buffer compositions affect spot morphology. Therefore, always perform a test print using the final buffer to examine the spots for bleeding or merging.

\section{Materials}

$30 \%$ glycerol

Pin/pin head cleaning solution (Arrayit), optional

384-well plate containing purified protein samples (Basic Protocol 1)

48-pin contact array printer (Genomics Solutions)

384-well plate

Kimwipes

UltraGAPS slides (Corning Life Sciences)

Glass slides

Centrifuge

1. Check the pin printing using $30 \%$ glycerol arrayed into a $384-$ well plate. Make sure all 48 pins are printing and positioned on the slide correctly.

Pins should be kept clean by sonication after each use. Single pins not touching the surface may be due to water or debris in the pin-holding block preventing the pins from moving down all the way. In other cases, where more thorough cleaning is needed, use pin/pin head cleaning solution to clean the pin/pin head.

2. Clean the stage of visible particles with Kimwipes for laying slides and lay out UltraGAPS slides in the printer. For the first few slides, lay out regular glass slides since initial printed spots tend to bleed during experiments.

FAST slides are available for radioactive and fluorescent probe experiments. Different surface chemistries yield different results therefore it is recommended to try different slides when developing an assay. For a comparison of slides refer to Balboni et al. (2008). 
3. Load the printing program that prints according to the layout plan for the protein array.

4. Centrifuge the 384 -well sample plate in a tabletop centrifuge for $30 \mathrm{sec}$ at $1000 \times g$, $4^{\circ} \mathrm{C}$, to collect the samples at the bottom of the wells.

5. Position the 384-well sample plate in the plate holder and press the operator button.

Each well will be spotted in duplicate, thereby increasing confidence of positive signals in the enzymatic assay. Each 384-well plate takes $~ 40 \mathrm{~min}$ to print 100 slides.

6. Replace the plates when prompted by the printer. Freeze the plates as soon as printing for that plate is complete.

Printed slides can be temporarily stored for a few days in a slide box at $-20^{\circ} \mathrm{C}$. For long-term storage (up to 1 year), maintain slides at $-80^{\circ} \mathrm{C}$. At this point slides can also be probed using an anti-HA antibody, followed by a fluorescently labeled secondary antibody to visualize protein spotting on the array.

\section{BASIC PROTOCOL 3: PERFORM RADIOACTIVE IN VITRO KINASE ASSAY ON A PROTEIN MICROARRAY}

Detailed here is a method for an in vitro kinase assay on a protein microarray. All radioisotope experiments follow the same general procedures. Use of appropriate buffers and inhibitors are important. Proper controls on the array are essential for interpretation and troubleshooting.

\section{Materials}

Three protein microarrays per kinase to be probed (e.g., from Basic Protocol 2)

Superblock/0.1\% Triton X-100 (Thermo/Fisher)

Kinase to be assayed, freshly prepared (1 to $50 \mathrm{nM}$ is required per probing)

Kinase buffer (see recipe)

Wash buffer (see recipe)

Milli-Q water

1-ml syringes

$0.45-\mu \mathrm{m}$ filter tips

Hybrislip hybridization coverslips (Grace Bio Labs)

Humidified chamber

50-ml conical tubes

Tabletop centrifuge

Plastic wrap 
Autoradiography film

High-resolution scanner

Photoshop

GenePix Software

1 Block three protein microarrays with Superblock/0.1\% Triton X-100 for $1 \mathrm{hr}$ at $4^{\circ} \mathrm{C}$. If using a slide box, $5 \mathrm{ml}$ per slide should be sufficient. In addition to a negative control array, perform each assay in duplicate on two separate arrays.

To reduce the likelihood of spots spilling onto neighboring spots or forming comet-like shapes, quickly submerge the slides by dropping the slide into a 50-ml Falcon tube filled with blocking solution, and then transfer to the slide box.

2 Prepare kinase mastermix by diluting the kinase of interest in kinase buffer containing $0.5 \mathrm{mg} / \mathrm{ml}$ bovine serum albumin, $0.1 \%$ Triton $\mathrm{X}-100$, and $33.3 \mathrm{nM}$, $20 \mu \mathrm{Ci}\left[\gamma^{32} \mathrm{P}\right] \mathrm{ATP}$ to a final volume of $400 \mu \mathrm{l}$ (200 $\mu \mathrm{l}$ for each positive array). Transfer the mastermix into a $1-\mathrm{ml}$ syringe fitted with a $0.45-\mu \mathrm{m}$ filter tip.

3 Prepare $200 \mu \mathrm{l}$ negative control mastermix (same as kinase mastermix, except omitting the kinase) and transfer into a second 1-ml syringe fitted with a 0.45 $\mu \mathrm{m}$ filter tip.

4 Overlay $200 \mu \mathrm{l}$ of the kinase mastermix onto each of two arrays, and $200 \mu \mathrm{l}$ of the negative control mastermix onto the third array.

5 Cover each array with a coverslip and place in a humidified chamber for $1 \mathrm{hr}$ at $30^{\circ} \mathrm{C}$.

6 Remove the coverslip. Wash the arrays twice with $45 \mathrm{ml}$ wash buffer and once with $45 \mathrm{ml}$ Milli-Q water.

To remove the coverslip, dip the slide and coverslip into 50-ml Falcon tube filled with wash buffer, allowing the coverslip to fall off by gravity. This minimizes scratching the slide surface.

$7 \quad$ Place each array carefully into a 50-ml conical tube. Centrifuge the arrays dry in tabletop centrifuge for $3 \mathrm{~min}$ at $500 \times \mathrm{g}, 4^{\circ} \mathrm{C}$.

8 Cover arrays with plastic wrap and expose to autoradiography film. Expose for $24 \mathrm{hr}$ or for several days if the signal is weak.

Alternatively, a tritium-sensitive phosphor screen on a Cyclone phosphorimager can be used.

If the signal is weak or absent, add more kinase to the reaction or let the reaction proceed longer (up to $6 \mathrm{hr}$ ). If the signal is too strong and little selectivity is observed, reduce the amount of kinase in the kinase mastermix by ten-fold. 


\section{Acquire and analyze data}

9 Obtain array images by scanning autoradiograph film on a high-resolution scanner set to $600 \mathrm{DPI}$.

Alternatively, scan a tritium-sensitive phosphorimager screen at 600 DPI.

10 Using Photoshop, crop the TIFF image file at 1-in. $\times 3$-in. fixed rectangular areas for each separate array. In a 16-bit digitizer mode, invert the image, set the image file size to $2550 \times 7650$ pixels and save as a new file.

11 Use GenePix software to overlay the mapping of yeast proteins in the array list file (.gal file) to each array image. After aligning each of the 48 subarrays, use the software to determine pixel intensities for each spot on the array.

Custom gal files can be created in two ways. GenePix software has a built-in function that accepts text files organized by 96-well plate and generates gal files. Alternatively, Microarray Convolutor offers more options for creating gal files (Cheung et al., 2002).

GenePix Result files (.gpr file) can be opened in other text editing or spreadsheet programs. The gpr files can be revised to work with ProCAT (Zhu et al., 2006). ProCAT is designed to work with protein microarray data. It corrects for background bias and spatial artifacts, identifies significant signals, filters nonspecific spots, and normalizes the resulting signal to protein abundance.

Alternatively, Prospector can be used to analyze the data. This software incorporates nearest neighbor analysis, background correction, Z-score transformation and replica covariance filtering.

\section{REAGENTS AND SOLUTIONS}

Use Milli-Q-purified water or equivalent in all recipes and protocol steps. For common stock solutions, see APPENDIX 2E; for suppliers, see SUPPLIERS APPENDIX.

\section{Blocking buffer}

Superblock (Thermo Scientific)

Triton X-100 to a final concentration of $0.1 \%$

Prepare fresh or 1 day prior to use

\section{Elution buffer}

$50 \mathrm{mM}$ Tris$\cdot \mathrm{Cl}, \mathrm{pH} 7.5$ (APPENDIX 2A)

$150 \mathrm{mM} \mathrm{NaCl}$

$30 \%$ glycerol

$0.1 \%$ Triton $\mathrm{X}-100$ 
Prepare fresh of 1 day prior to use

Kinase buffer (specific to kinase of interest, but typically use the following recipe)

20 mM HEPES, pH 7.4

$150 \mathrm{mM} \mathrm{NaCl}$

$10 \mathrm{mM} \mathrm{MgCl} 2$

$0.1 \%$ Triton $\mathrm{X}-100$

$25 \%(\mathrm{v} / \mathrm{v})$ glycerol $0.5 \mathrm{mg} / \mathrm{ml} \mathrm{BSA}$

$\gamma-\left[{ }^{33} \mathrm{P}\right]-\mathrm{ATP}$ or $\gamma-\left[{ }^{32} \mathrm{P}\right]-\mathrm{ATP}, 10 \mu \mathrm{Ci} / \mu \mathrm{l}, 3000 \mathrm{Ci} / \mathrm{mmol}$

Prepare fresh

If using $\gamma-\left[{ }^{32} \mathrm{P}\right]-\mathrm{ATP}$, all handling of the isotope should be done behind an acrylic shield. Disposal of radioactive waste should be according to the guidelines of your institution.

Lysis buffer 1

$50 \mathrm{mM}$ Tris.Cl, pH 7.5 (APPENDIX 2A)

$150 \mathrm{mM} \mathrm{NaCl}$

$10 \%$ glycerol

$0.1 \%$ Triton $\mathrm{X}-100$

1 mM EGTA

$0.5 \mathrm{mM}$ DTT

$1 \mathrm{mM}$ PMSF

Protease inhibitor tablets used as recommended by manufacturer (Roche)

Phosphatase inhibitor tablets used as recommended by manufacturer (Roche)

Prepare fresh or 1 day prior to use

Lysis buffer 2

$50 \mathrm{mM}$ Tris·Cl, $\mathrm{pH} 7.5$ (APPENDIX 2A)

$650 \mathrm{mM} \mathrm{NaCl}$

$10 \%$ glycerol

$0.1 \%$ Triton $\mathrm{X}-100$

1 mM EGTA

$0.5 \mathrm{mM}$ DTT

$1 \mathrm{mM}$ PMSF

Protease inhibitor tablets used as recommended by manufacturer (Roche)

Curr Protoc Protein Sci. Author manuscript; available in PMC 2015 April 29. 
Phosphatase inhibitor tablets used as recommended by manufacturer (Roche)

Prepare fresh or 1 day prior to use

Lysis buffer 3

$50 \mathrm{mM}$ Tris $\cdot \mathrm{Cl}, \mathrm{pH} 7.5($ APPENDIX 2A)

$10 \%$ glycerol

$0.1 \%$ Triton $\mathrm{X}-100$

1 mM EGTA

$0.5 \mathrm{mM}$ DTT

$1 \mathrm{mM}$ PMSF

Protease inhibitor tablets used as recommended by manufacturer (Roche)

Phosphatase inhibitor tablets used as recommended by manufacturer (Roche)

Prepare fresh or 1 day prior to use

\section{SC-ura medium, agar plates and liquid}

$1.7 \mathrm{~g}$ yeast nitrogen base without amino acids (Inotek)

$5 \mathrm{~g}$ ammonium sulfate,

$2 \mathrm{~g}$-ura dropout mix (Inotek)

$20 \mathrm{~g}$ dextrose in MilliQ water to a final volume of 1 liter

Autoclave

Store up to 6 months at $4^{\circ} \mathrm{C}$

For plates, add $20 \mathrm{~g}$ bacto-agar before autoclaving.

\section{SC-ura/raffinose medium, liquid}

$1.7 \mathrm{~g}$ yeast nitrogen base without amino acids

$5 \mathrm{~g}$ ammonium sulfate

$2 \mathrm{~g}$-ura dropout mix (Inotek)

$20 \mathrm{~g}$ raffinose in $\mathrm{H}_{2} \mathrm{O}$ to a final volume of 1 liter

Autoclave

Store up to 6 months at $4^{\circ} \mathrm{C}$

$3 \times \mathrm{YP}+6 \%$ galactose (yeast extract, peptone, and galactose)

Dissolve $30 \mathrm{~g}$ yeast extract and $60 \mathrm{~g}$ peptone in $700 \mathrm{ml} \mathrm{H}_{2} \mathrm{O}$

Autoclave

Add $300 \mathrm{ml}$ filter-sterilized $20 \%$ (w/v) galactose 
Store up to 6 months at $4^{\circ} \mathrm{C}$ after autoclaving

NOTE: Galactose should NOT be autoclaved.

\section{Wash buffer}

$10 \mathrm{mM}$ Tris$\cdot \mathrm{Cl} \mathrm{pH} 7.5$ (APPENDIX 2A)

$0.5 \%$ SDS

Store up to 1 month at $4^{\circ} \mathrm{C}$

\section{COMMENTARY}

\section{Background Information}

Functional protein microarrays are best used for quickly examining an entire proteome with precise control of reaction conditions in an unbiased fashion. Because of the construction method, even low abundance proteins can be accommodated.

Protein microarray technology has a few shortcomings. First, the extent of protein array content that can be obtained is dependent on availability of sequence information of the specific organism of interest. Thus, isoforms of a protein are usually not represented. Second, due to the nature of manufacturing proteins for spotting, the protein can have different modifications or other tightly interacting proteins can co-purify. Expressing the protein using a cell-free system can control for such issues. Third, in addition to identifying true protein interactions, protein microarray experiments often identify false-positive protein interactions due to the in vitro nature of the assay. Thus, some previous knowledge of the system is required to filter out off-target results, and a validation strategy is required. Fourth, typical interrogation of protein microarrays is done with one or two probes/enzymes, which limits throughput. Assay refinements are under development to increase the sensitivity and reduce the amount of protein required (Tabakman et al., 2011), which eventually will reduce the cost per experiment. Development of better multiplexing technologies will also contribute to increased performance and reduced cost.

\section{Critical Parameters}

Background signals from different protein microarray experiments will differ and will require statistical analysis. In addition, to assess the quality of spotted arrays, randomly selected slides from each print batch are probed with anti-GST antibodies. All spots should show signals and, most ideally, should have relatively equal intensity. To increase the confidence of the assay, it is recommended to probe five arrays per condition.

The kinase assay can be optimized to increase the number of positive hits or reduce noise. It has been reported that about $75 \%$ of kinases tested in yeast did not show any difference in kinase activity depending on the absence or presence of BSA. However, the remaining $25 \%$ displayed a marked difference in activity between the two conditions (Meng et al., 2008).

One other factor that will influence the detection of kinase substrates is a priming effect, which requires phosphorylation of a separate site by a different kinase in order for the kinase of interest to phosphorylate its cognate site. Lastly, phosphorylation sites can be masked by 
exogenous kinases during preparation of substrates. This masking can be reversed by phosphatase treatment of the substrates during preparation.

\section{Troubleshooting}

Table 27.4.1 lists some common problems encountered when performing the protocols described in this unit, along with explanations of likely causes and recommendations for overcoming or avoiding these problems.

\section{Anticipated Results}

This assay produces an array of spots with varying intensities representing the extent of phosphorylation of each protein (Fig. 27.4.1). The data is then filtered by subtracting out autophosphorylating proteins, as identified from the negative control assay. Typically, with fluorescence assays, less than 5\% cross variation is observed for duplicate spots on a single array, with $15 \%$ to $20 \%$ variation between arrays. With radioactive assays such as this one, cross variability is slightly higher. Kinases exhibit a wide range of specificities, with some kinases targeting hundreds of substrates and others targeting only a single substrate (Ptacek et al., 2005).

\section{Time Considerations}

Construction of an array can take several months for proteome-wide-scale arrays. Once the expression clone collection is ready the yeast proteome arrays can be constructed as follows (times assume two $\sim$ three workers): Growth of yeast cells will take $\sim 2$ days for every four 96 -well plates and $\sim 3$ weeks for 5500 clones by staggering the cultures. Purification of proteins for every four 96 -well plates takes $\sim 20 \mathrm{hr}$ including overnight pro-tease treatment and $\sim 2$ weeks for the entire yeast proteome. Printing a protein array takes $\sim 12 \mathrm{hr}$ for 100 slides.

\section{Acknowledgments}

The authors thank Dr. George Mias and Erin Mitsunaga for their comments and discussion.

\section{Literature Cited}

Balboni I, Limb C, Tenenbaum JD, Utz PJ. Evaluation of microarray surfaces and arraying parameters for autoantibody profiling. Proteomics. 2008; 8:3443-3449. [PubMed: 18752214]

Brizuela L, Braun P, LaBaer J. FLEX-Gene repository: From sequenced genomes to gene repositories for high-throughput functional biology and proteomics. Mol Biochem Parasitol. 2001; 118:155165. [PubMed: 11738706]

Bussow K, Nordhoff E, Lubbert C, Lehrach H, Walter G. A human cDNA library for high-throughput protein expression screening. Genomics. 2000; 65:1-8. [PubMed: 10777659]

Cheung KH, Hager J, Nelson K, White K, Li Y, Snyder M, Williams K, Miller P. A dynamic approach to mapping coordinates between microplates and microarrays. J Biomed Informatics. 2002; 35:306312.

Fasolo J, Sboner A, Sun MG, Yu H, Chen R, Sharon D, Kim PM, Gerstein M, Snyder M. Diverse protein kinase interactions identified by protein microarrays reveal novel connections between cellular processes. Genes Dev. 2011; 25:767-778. [PubMed: 21460040]

Gelperin DM, White MA, Wilkinson ML, Kon Y, Kung LA, Wise KJ, Lopez-Hoyo N, Jiang L, Piccirillo S, Yu H, Gerstein M, Dumont ME, Phizicky EM, Snyder M, Grayhack EJ. Biochemical 
and genetic analysis of the yeast proteome with a movable ORF collection. Genes Dev. 2005; 19:2816-2826. [PubMed: 16322557]

Graslund S, Nordlund P, Weigelt J, Hallberg BM, Bray J, Gileadi O, Knapp S, Oppermann U, Arrowsmith C, Hui R, Ming J, dhe-Paganon S, Park HW, Savchenko A, Yee A, Edwards A, Vincentelli R, Cambillau C, Kim R, Kim SH, Rao Z, Shi Y, Terwilliger TC, Kim CY, Hung LW, Waldo GS, Peleg Y, Albeck S, Unger T, Dym O, Prilusky J, Sussman JL, Stevens RC, Lesley SA, Wilson IA, Joachimiak A, Collart F, Dementieva I, Donnelly MI, Eschenfeldt WH, Kim Y, Stols L, Wu R, Zhou M, Burley SK, Emtage JS, Sauder JM, Thompson D, Bain K, Luz J, Gheyi T, Zhang F, Atwell S, Almo SC, Bonanno JB, Fiser A, Swaminathan S, Studier FW, Chance MR, Sali A, Acton TB, Xiao R, Zhao L, Ma LC, Hunt JF, Tong L, Cunningham K, Inouye M, Anderson S, Janjua H, Shastry R, Ho CK, Wang D, Wang H, Jiang M, Montelione GT, Stuart DI, Owens RJ, Daenke S, Schutz A, Heinemann U, Yokoyama S, Bussow K, Gunsalus KC. Protein production and purification. Nat Methods. 2008; 5:135-146. [PubMed: 18235434]

Hu S, Xie Z, Onishi A, Yu X, Jiang L, Lin J, Rho HS, Woodard C, Wang H, Jeong JS, Long S, He X, Wade H, Blackshaw S, Qian J, Zhu H. Profiling the human protein-DNA interactome reveals ERK2 as a transcriptional repressor of interferon signaling. Cell. 2009; 139:610-622. [PubMed: 19879846]

Hudson JR Jr, Dawson EP, Rushing KL, Jackson CH, Lockshon D, Conover D, Lanciault C, Harris JR, Simmons SJ, Rothstein R, Fields S. The complete set of predicted genes from Saccharomyces cerevisiae in a readily usable form. Genome Res. 1997; 7:1169-1173. [PubMed: 9414322]

Lennon G, Auffray C, Polymeropoulos M, Soares MB. The I.M.A.G.E. Consortium: an integrated molecular analysis of genomes and their expression. Genomics. 1996; 33:151-152. [PubMed: 8617505]

MacBeath G, Schreiber SL. Printing proteins as microarrays for high-throughput function determination. Science. 2000; 289:1760-1763. [PubMed: 10976071]

Meng L, Michaud GA, Merkel JS, Zhou F, Huang J, Mattoon DR, Schweitzer B. Protein kinase substrate identification on functional protein arrays. BMC Biotechnol. 2008; 8:22. [PubMed: 18307815]

Popescu SC, Popescu GV, Bachan S, Zhang Z, Seay M, Gerstein M, Snyder M, Dinesh-Kumar SP. Differential binding of calmodulin-related proteins to their targets revealed through high-density Arabidopsis protein microarrays. Proc Natl Acad Sci USA. 2007; 104:4730-4735. [PubMed: 17360592]

Ptacek J, Devgan G, Michaud G, Zhu H, Zhu X, Fasolo J, Guo H, Jona G, Breitkreutz A, Sopko R, McCartney RR, Schmidt MC, Rachidi N, Lee SJ, Mah AS, Meng L, Stark MJ, Stern DF, De Virgilio C, Tyers M, Andrews B, Gerstein M, Schweitzer B, Predki PF, Snyder M. Global analysis of protein phosphorylation in yeast. Nature. 2005; 438:679-684. [PubMed: 16319894]

Reboul J, Vaglio P, Rual JF, Lamesch P, Martinez M, Armstrong CM, Li S, Jacotot L, Bertin N, Janky R, Moore T, Hudson JR Jr, Hartley JL, Brasch MA, Vandenhaute J, Boulton S, Endress GA, Jenna S, Chevet E, Papasotiropoulos V, Tolias PP, Ptacek J, Snyder M, Huang R, Chance MR, Lee H, Doucette-Stamm L, Hill DE, Vidal M. C. elegans ORFeome version 1.1: Experimental verification of the genome annotation and resource for proteome-scale protein expression. Nat Genet. 2003; 34:35-41. [PubMed: 12679813]

Schweitzer B, Kingsmore SF. Measuring proteins on microarrays. Curr Opin Biotechnol. 2002; 13:1419. [PubMed: 11849952]

Strausberg RL, Feingold EA, Klausner RD, Collins FS. The mammalian gene collection. Science. 1999; 286:455-457. [PubMed: 10521335]

Strausberg RL, Feingold EA, Grouse LH, Derge JG, Klausner RD, Collins FS, Wagner L, Shenmen CM, Schuler GD, Altschul SF, Zeeberg B, Buetow KH, Schaefer CF, Bhat NK, Hopkins RF, Jordan H, Moore T, Max SI, Wang J, Hsieh F, Diatchenko L, Marusina K, Farmer AA, Rubin GM, Hong L, Stapleton M, Soares MB, Bonaldo MF, Casavant TL, Scheetz TE, Brownstein MJ, Usdin TB, Toshiyuki S, Carninci P, Prange C, Raha SS, Loquellano NA, Peters GJ, Abramson RD, Mullahy SJ, Bosak SA, McEwan PJ, McKernan KJ, Malek JA, Gunaratne PH, Richards S, Worley KC, Hale S, Garcia AM, Gay LJ, Hulyk SW, Villalon DK, Muzny DM, Sodergren EJ, Lu X, Gibbs RA, Fahey J, Helton E, Ketteman M, Madan A, Rodrigues S, Sanchez A, Whiting M, Madan A, Young AC, Shevchenko Y, Bouffard GG, Blakesley RW, Touchman JW, Green ED, Dickson MC, Rodriguez AC, Grimwood J, Schmutz J, Myers RM, Butterfield YS, Krzywinski MI, 
Skalska U, Smailus DE, Schnerch A, Schein JE, Jones SJ, Marra MA. Generation and initial analysis of more than 15,000 full-length human and mouse cDNA sequences. Proc Natl Acad Sci USA. 2002; 99:16899-16903. [PubMed: 12477932]

Tabakman SM, Lau L, Robinson JT, Price J, Sherlock SP, Wang H, Zhang B, Chen Z, Tangsombatvisit S, Jarrell JA, Utz PJ, Dai H. Plasmonic substrates for multiplexed protein microarrays with femtomolar sensitivity and broad dynamic range. Nat Communications. 2011; 2:466.

Tsvetanova NG, Klass DM, Salzman J, Brown PO. Proteome-wide search reveals unexpected RNAbinding proteins in Sac-charomyces cerevisiae. PLoS One. 2010; 5:e12671. [PubMed: 20844764]

Zhu H, Bilgin M, Bangham R, Hall D, Casamayor A, Bertone P, Lan N, Jansen R, Bidlingmaier S, Houfek T, Mitchell T, Miller P, Dean RA, Gerstein M, Snyder M. Global analysis of protein activities using proteome chips. Science. 2001; 293:2101-2105. [PubMed: 11474067]

Zhu X, Gerstein M, Snyder M. ProCAT: a data analysis approach for protein microarrays. Genome Biol. 2006; 7:R110. [PubMed: 17109749] 


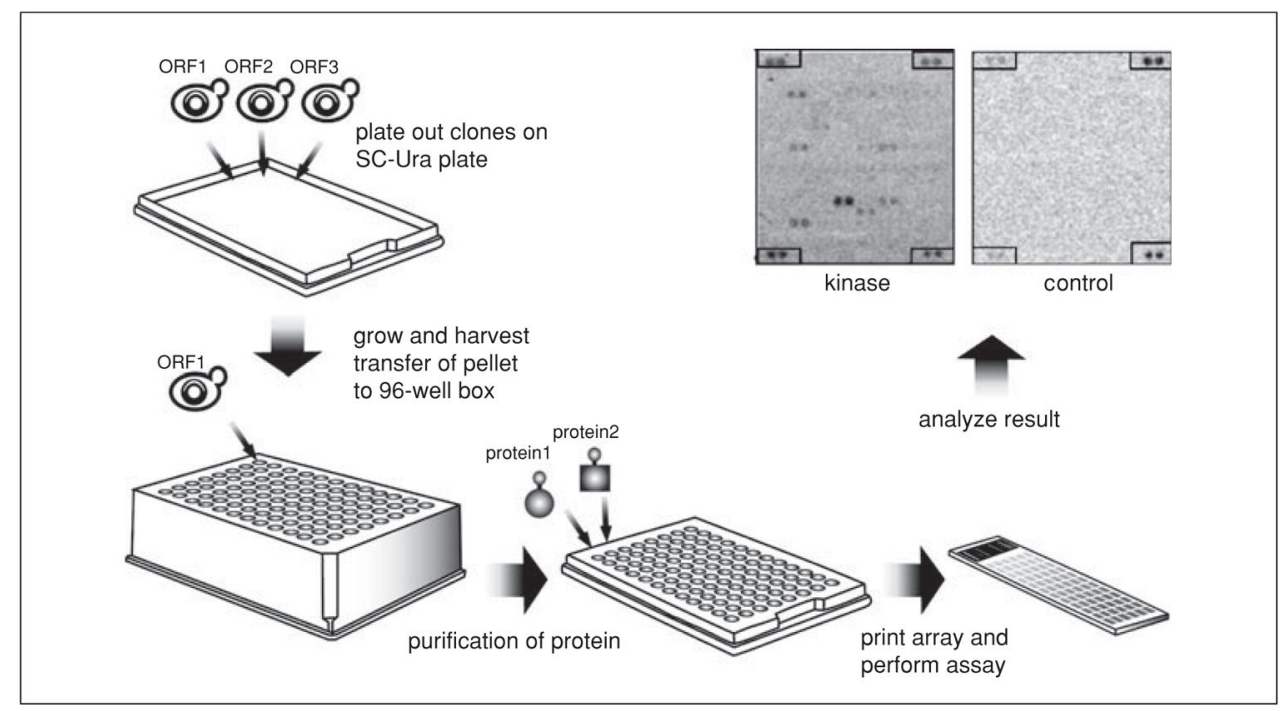

Figure 27.4.1.

Schematic diagram of overall protocol. Yeast clones containing cDNA constructs are plated on selection medium. Each clone is grown and protein expression is induced. Pellets of each clone are transferred into 96-well boxes. Fusion proteins are purified and transferred to 96well titer plates for printing on slides. In the upper right, the kinase-treated block shows spots, which indicate phosphorylation of printed proteins with radioactive phosphate. Spots in the corner rectangles are positive controls. 
Table 27.4.1

Troubleshooting Spotted Arrays

\begin{tabular}{lll}
\hline Problem & Possible reason & Possible solution \\
\hline $\begin{array}{l}\text { Outgrowth cultures are ready to } \\
\text { induce at different times. }\end{array}$ & $\begin{array}{l}\text { Starter cultures contain different numbers } \\
\text { of senescing cells. }\end{array}$ & $\begin{array}{l}\text { Inoculate starter cultures from patches freshly selected } \\
\text { from frozen glycerol stocks. }\end{array}$ \\
$\begin{array}{l}\text { Not all } 48 \text { pins are printing round, } \\
\text { even spots. }\end{array}$ & $\begin{array}{l}\text { Water or debris in the pin-holding block } \\
\text { may be preventing certain pins from going } \\
\text { down all the way. }\end{array}$ & $\begin{array}{l}\text { Carefully clean the pins using 70\% (v/v) ethanol and a } \\
\text { cotton swab. Water bath sonication also helps to clean the } \\
\text { pins. }\end{array}$ \\
$\begin{array}{l}\text { Autoradiography signal is weak or } \\
\text { absent. }\end{array}$ & $\begin{array}{l}\text { Kinase preparation has weak activity. } \\
\text { Repeat assay extending the reaction time up to 6 hr, } \\
\text { adding more kinase to the kinase mastermix, and/or } \\
\text { expose assay to autoradiography film longer (up to } \\
\text { several days). }\end{array}$ \\
$\begin{array}{l}\text { Autoradiography signal is too } \\
\text { strong, and little selectivity is } \\
\text { observed. }\end{array}$ & $\begin{array}{l}\text { Kinase preparation has strong activity } \\
\text { and/or contains contaminating kinases. }\end{array}$ & $\begin{array}{l}\text { Repeat assay reducing the amount of kinase in the kinase } \\
\text { mastermix by 10-fold. }\end{array}$ \\
$\begin{array}{l}\text { Autoradiography signals from } \\
\text { neighboring spots bleed together. }\end{array}$ & $\begin{array}{l}\text { Spots of highly expressed proteins did not } \\
\text { dry thoroughly onto the slide surface } \\
\text { before storage or blocking. }\end{array}$ & $\begin{array}{l}\text { Allow freshly printed/thawed slides to dry 20 min before } \\
\text { blocking }\end{array}$ \\
\hline
\end{tabular}

